\title{
Lonely older people as a problem in society - construction in Finnish media
}

\author{
By Hanna Uotilat, ${ }^{1,2}$ Kirsi Lumme-SAndt ${ }^{1}$ \& Marja \\ SAARENHEIMO ${ }^{3}$
}

\begin{abstract}
Loneliness is a prevalent stereotype of old age but there is a lack of studies of how it is represented in mass media. This study examines how the loneliness of older people is portrayed in mass media. The research material consists of 154 texts from the leading $50+$ magazines and daily newspapers in Finland. In the texts, loneliness was rarely seen solely as a lack of companionship and many negative attributes were connected to it. Among other things, loneliness was connected to the low status of older people in society, inhumane practices in elderly care, lack of meaning in life and neglect by relatives. Loneliness was also viewed as an inevitable part of ageing. However, many suggestions were made to alleviate loneliness. The extent of these suggestions varied from broad and collective actions to simple and perfunctory solutions.
\end{abstract}

Keywords: loneliness, older people, qualitative study, mass media.

\footnotetext{
${ }^{1}$ Hanna Uotila and Kirsi Lumme-Sandt, Tampere School of Public Health, University of Tampere, Finland

${ }^{2}$ Hanna Uotila, The Science Center of Pirkanmaa Hospital District, Tampere, Finland

${ }^{3}$ Marja Saarenheimo, The Central Union for the Welfare of the Aged, Helsinki, Finland
} 
International Journal of Ageing and Later Life

\section{Introduction}

The concept of loneliness has been interpreted and defined in various ways. In most studies, loneliness is understood as a negative feeling or an unpleasant and distressing experience of a lack of social contacts (Peplau \& Perlman 1982). Victor et al. (2005) emphasised a discrepancy between the actual and desired quality and quantity of social engagement. Two dimensions of loneliness have been postulated. Weiss (1973) distinguished between emotional and social loneliness. Emotional loneliness arises in situations where a reliable or intimate relationship is lacking, and social loneliness is caused by absence of social networks.

Scientific texts often define social isolation and loneliness as distinct but interrelated concepts. Social isolation refers to an objective, measurable state of having minimal contact with other people while the experience of loneliness refers to a subjective state that is recognisable only by the person in question (Jylhä \& Saarenheimo 2010; Victor et al. 2000, 2005). A person may suffer from loneliness even when surrounded by other people.

Loneliness has different meanings for different people and in different contexts. It has been seen as a highly subjective experience. In everyday talk, loneliness has several related meanings that are partly overlapping. Loneliness can be addressed by using different words. By talking about the time spent alone one can refer to feelings of loneliness, but not always and not necessarily. Being or living alone can also indicate a specific type of the household arrangement (Victor et al. 2000). Living alone can also be constructed as a neutral aloneness or a positive solitude (Pierce et al. 2003). However, there are no separate concepts for negative and positive loneliness in Finnish.

Traditionally, a particularly strong relationship has been postulated between loneliness and old age. In everyday talk and media, and also in academic studies, loneliness is frequently constructed as a common and intensive feeling in old age, and its prevalence has even been dramatised (Wenger \& Burholt 2004). However, surveys have reported that the majority (two-thirds) of older people do not suffer from loneliness (Savikko et al. 2005; Steed et al. 2007; Victor et al. 2005). It seems that there is a discrepancy between the public understanding and academic surveys about the frequency of loneliness in old age. The discrepancy may arise from common conceptions of loneliness as a harmful, painful and 
thoroughly negative feeling. According to the surveys, only one-third of older people feel lonely, but the prevalence of feelings of loneliness increases with age. This is not explained by age itself, but rather by changes and losses in health, functional capacity and social networks (Jylhä 2004; Savikko et al. 2005; Victor et al. 2005).

Public images of old age and loneliness of older people are partly constructed by mass media. Traditionally, public images of old age have been twofold. Old age has either been considered a time of frailty and loss or a time of wisdom and experience. Apart from these, a third view has appeared; one that represents agelessness and incessant activity as attributes of successful ageing. Despite the current focus on the active third age (Laslett 1989; Weiss \& Bass 2002), negative stereotypes of old age still exist. Media studies have shown that these also appear in mass media (Ellis \& Morrison 2005). Especially before the mid-1980s, foolish, senile, bitter or feeble minded characters represented old age in the media (Williams et al. 2010). At the same time there was generally an underrepresentation of older people in the media (Bazzini et al. 1997; Zhang et al. 2006). This solely negative portrayal and the under-representation of older people seem to be changing. Predominantly negative images have over the last decades been modified in different types of media by a tendency that Vincent (2003), among others, calls "the liberation of old age" and replaced by more positive images (Miller et al. 1999, 2004; Roy \& Harwood 1997; Williams et al. 2007, 2010; Zhang et al. 2006). Older people are now more likely to be represented as actors and in roles which break the former stereotypes of older people. Today, older people, particularly the third agers, also tend to appear more often in media. Magazines for active and healthy older people have emerged. Those magazines foster a positive self-image and a healthier and more positive lifestyle for older people (Lumme-Sandt 2010; Williams et al. 2007).

In recent years, research on media representations of older people has increased. Several studies have focused on media portrayals of ageing, especially in the USA (Zhang et al. 2006). However, the stereotype of lonely old age has not been studied in the context of mass media. Stereotypes of old age have an impact on how ageing is understood and what is possible and appropriate in later life. They also affect the way old people are treated in society and how elderly people see themselves 
International Journal of Ageing and Later Life

(Bazzini et al. 1997; Horton et al. 2007). Overly positive portrayals of later life as a care-free zone are as unrealistic as the portrayals of later life as a zone of decline and sickness. Therefore, more research is needed in this specific area.

In this study we approach loneliness pragmatically, based not on academic definition but on "everyday definitions" appearing in our data. We explore whether and how loneliness of older people is portrayed in the leading $50+$ magazines and daily newspapers in Finland. The purpose of our analysis is to identify how loneliness is formulated and defined in media. The general aim of this study is to explore how loneliness of older people is constructed in public talk: what is written about loneliness and what positions do the writers adopt.

\section{Material and Method}

The data for the study were drawn from a widely read magazine and the largest daily newspaper in Finland. ET magazine (ET) was chosen because it is the most popular general-interest magazine for people over 50 years of age in Finland. Originally aimed for retired people, the readership of ET now includes people over 50. ET focuses on the third age (Lumme-Sandt 2010). It offers human interest articles and features on well-being, travel, food, fashion and hobbies (Sanoma Magazines Finland 2009; Toppila 2009). Helsingin Sanomat (HS) was chosen because it is the leading national newspaper in Finland. HS has a significant role in shaping the public opinion in Finland. It reaches 22\% of Finns (Medianetti 2009) (see Table 1). Together these two very different representatives of print media give a fairly comprehensive view of how old age loneliness is represented in Finnish print media.

Table 1. Readers of the ET and the HS in 2007 (\%)

\begin{tabular}{lcc}
\hline & ET & HS \\
\hline Readers: age $50+$ & 80 & 49 \\
Readers: women & 74 & 48 \\
Reach of Finns: age $50+$ & 33 & 24 \\
\hline
\end{tabular}

Source: Finnish Audit Bureau of Circulations (2009). 
The data comprise all editions of ET and HS in 5 years (years 2003-2007). The composition of the data set and the basic steps of analysis are shown in Figure 1. Two criteria were set down for inclusion of a given text in the data set: the text must deal with loneliness and

Figure 1. Data composition and data analysis.

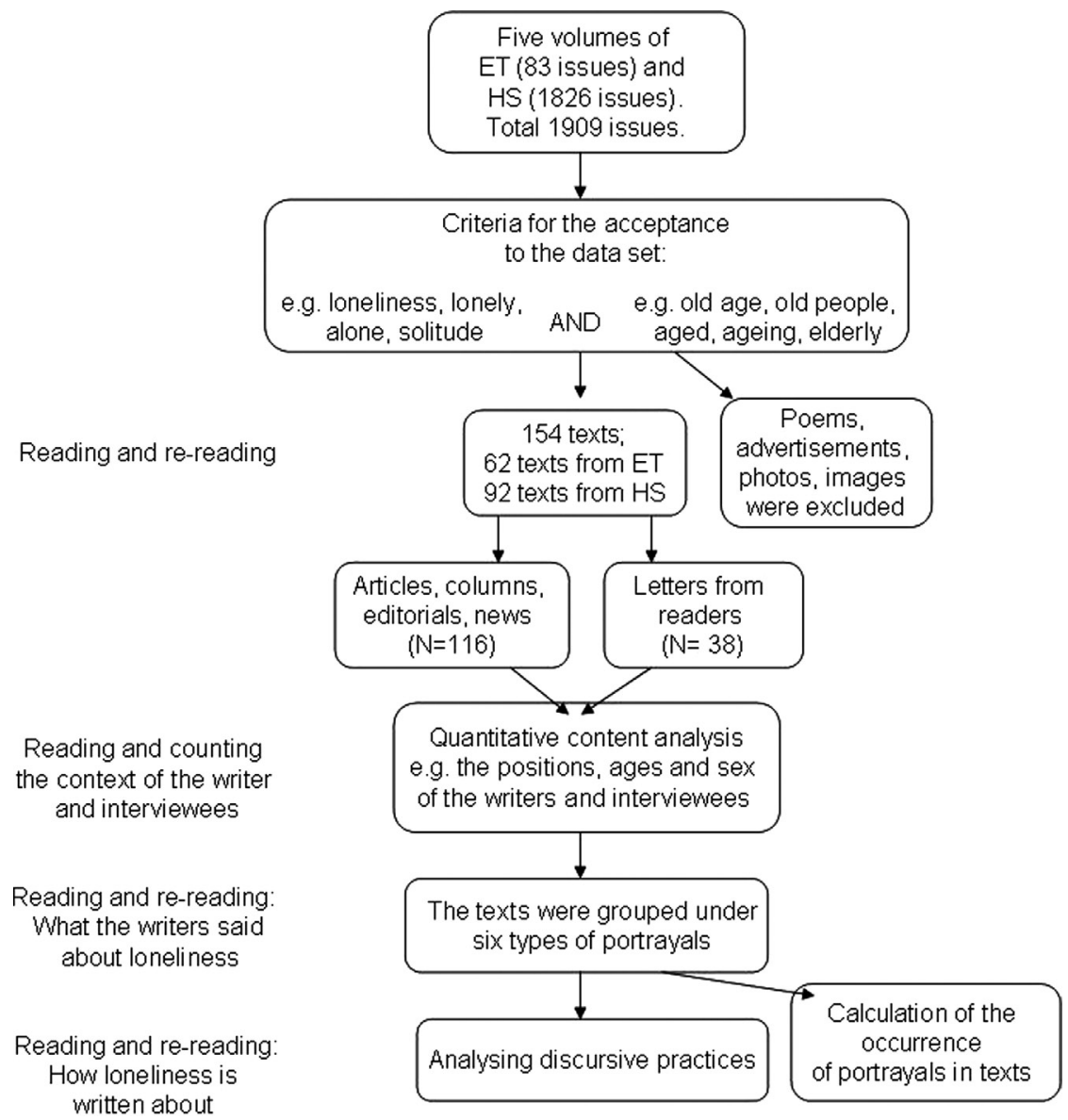


International Journal of Ageing and Later Life

ageing. Loneliness and other related words were used as a starting point for the collection of data. The five volumes of the printed editions of ET were read and the texts that dealt with loneliness and older people or old age were identified. Because of the large number of issues of HS, the texts were searched through the online archives. Different combinations of key words in Finnish were used, including loneliness, lonely, alone, old age, older people and ageing. All texts were read in order to determine whether they actually dealt with loneliness and ageing. Two text types were excluded from the data: poems because of their ambiguousness and advertisements because they serve economic purposes. Also photos and images were excluded from the data because the pictures and photos in HS were not available on the online archives. The final data set consists of 154 texts, 62 from ET and 92 from HS. There were considerable differences between the texts. They were written from different positions and had different intentions. There were articles, news, editorials and columns written by journalists (116) as well as letters written by readers (38) (see Figure 1).

First, we classified the contexts of the writers and interviewees. The data were heterogeneous. The writers included both women and men, although women were slightly more likely to write than men. The writers and interviewees represented a wide variety of social and occupational groups, and thus occupied different positions, although a position cannot be defined simply by occupation or social group. The writers included leaders of non-governmental organisations, medical doctors, journalists, researchers, singers, novelists, voluntary and church workers, and relatives of older people and old people themselves. More than half of the writers or interviewees, who have mentioned their occupation, came from the field of culture and caring/medicine or were leaders of various organisations (see Table 2). The explicit motives for the accounts varied. Some writers emphasised their occupational position, whereas others were speaking as citizens or as interested parties such as relatives or older persons. Loneliness was approached both from academic and lay perspectives. However, these different discourses were often intermingled even in texts written by professionals such as leaders of non-governmental organisations, medical doctors and researchers. Loneliness seems to be a diverse phenomenon, which is rarely addressed from only one position. Even 
Table 2. Amount of writers and main interviewees in the texts by separate occupational groups $(N=161)$

Leaders of non-governmental organisations

Field of culture

$\begin{array}{lr}\text { Field of caring and medicine } & 23\end{array}$

Researchers $\quad 18$

$\begin{array}{lr}\text { Church workers } & 16\end{array}$

$\begin{array}{lr}\text { Journalists } & 16\end{array}$

Politician 3

$\begin{array}{lr}\text { Others (e.g. retiree, student, other occupation) } & 15\end{array}$

Not mentioned $\quad 22$

professionals use their own personal experiences and emotions when dealing with the issue.

Second, we searched for the different portrayals of old age loneliness in the texts. This was done by analysing what the writers said about the causes, meanings, consequences and correlates of loneliness in old age. The analysis thus served the identification of different everyday conceptions and theories, and explanations given to loneliness. In accordance with a discourse analytic perspective (Wetherell et al. 2001; Wood \& Kroger 2000), the analysis was not based on any specific definition of loneliness or any social gerontological theory. Applying definitions or theories at this stage would have narrowed the scope of the analysis, since our aim was exploratory rather than definition-based. The discourse analytic approach means that the analysis is based on the data, and the meanings given to loneliness by ordinary people themselves are studied in their social and cultural contexts. Writers' accounts are highly contextspecific. The accounts construct different versions of the social world and serve different functions. Variability exists between persons and even within persons/texts. The texts use formulations available in current society, and therefore isolated accounts cannot be analysed outside the cultural and societal context in which they are produced (Edley 2001; Taylor 2001; Wood \& Kroger 2000). Following the more thorough analysis, the texts were grouped under six types of portrayals of old age loneliness. The occurrence of the portrayals in different text types was counted and this information was studied in the context of the writers' positions. It was 
International Journal of Ageing and Later Life

thus possible to identify relations and differences between the writer's position and the manner and content of writing (Table 3).

Finally, we performed a detailed analysis of the discourses used in writing about loneliness, and the positions taken by the writers and given to older people. Here, the concept of subject position was used and it was defined as a location within a context. Within a single text, different discourses can be used, different positions adopted and different audiences addressed (Edley 2001; Wood \& Kroger 2000). The concept of discourse is used here in a broad sense, referring to the ways of thinking and writing about loneliness in different everyday encounters, and also as ways of organising society and positions of individual people within society, which then have consequences for people's lives (Miller 2008; Wetherell \& Edley 1999). In this study, a pragmatic perspective is adopted, where language is seen as a vehicle in performing a variety of social acts. Discourse analysis offers tools for exploring different and sometimes conflicting meanings attached to loneliness of older people (Edley 2001; Taylor 2001). Attention was also paid to the different nuances of language, choice of words, writing styles and metaphors. Since the focus of the study was on old age loneliness in print media, the analysis concentrated on how the loneliness of older people was constructed in the texts, on the

Table 3. Portrayals of old age loneliness (\%)

\begin{tabular}{lccccc}
\hline & $\begin{array}{c}\text { Articles } \\
N=144\end{array}$ & $\begin{array}{c}\text { News } \\
N=34\end{array}$ & $\begin{array}{c}\text { Editorials } \\
N=43\end{array}$ & $\begin{array}{c}\text { Columns } \\
N=35\end{array}$ & $\begin{array}{r}\text { Letters } \\
N=75\end{array}$ \\
\hline $\begin{array}{l}\text { Lack of human } \\
\text { relationships }\end{array}$ & 42 & 41 & 32 & 26 & 29 \\
$\begin{array}{l}\text { Forgotten by } \\
\text { society }\end{array}$ & 22 & 35 & 49 & 40 & 38 \\
$\begin{array}{l}\text { Lack of meaning } \\
\text { in life }\end{array}$ & 21 & 24 & 12 & 23 & 16 \\
$\begin{array}{l}\text { Neglect of older } \\
\text { people by relatives }\end{array}$ & 6 & 0 & 0 & 8 & 9 \\
$\begin{array}{l}\text { Inevitable part of } \\
\text { old age }\end{array}$ & 3 & 0 & 5 & 3 & 4 \\
$\begin{array}{l}\text { Positive loneliness } \\
\text { Old }\end{array}$ & 6 & 0 & 2 & 0 & 4 \\
& 100 & 100 & 100 & 100 & 100 \\
\hline
\end{tabular}


intentions and expected consequences of the texts, and on the meanings attached to loneliness.

\section{What Do People Say When They Write About Loneliness?}

Six different portrayals of old age loneliness were identified in the data set (see Table 3). Even if the writers wrote from different positions and had different motives for writing, nearly all portrayals appear in every text type. There are no major differences between text types, except in the last three portrayals (Table 3). Lack of human relationship appeared most often in the texts; a little more often in articles and news than in other text types. Forgotten by society is mentioned more often in editorials, columns and letters than in other text types. It seems that writing about one's own thoughts and opinions invites to write about loneliness from this point of view. These two portrayals are most general in all text types. Lack of meaning in life appeared fairly often in all text types. Neglect of older people by relatives, positive loneliness and inevitable part of old age are very rarely present in the data and there are text types where these portrayals were entirely absent.

As can be seen in Table 3, it is not relevant to argue that loneliness is constructed differently in different text types. There are some differences in the emphasis between text types. However, a single text can characterise loneliness in different or even opposite ways. The next extract is a good example of this phenomenon. It shows how a single writer can write about loneliness employing several different portrayals. The text is an extract from a letter written by a reader.

... What would you think if nobody had time to come and visit you anymore? How would you feel if your children had the time to take a two-week vacation in Spain and a weeklong skiing vacation in Lapland, but not for Mothers' Day, for just a very short visit to you, bringing along one more set of bed sheets or a tablecloth to put to the chest of drawers? And you weren't even able to change the sheets, and your lamp was broken last autumn, and nobody has replaced it. ... Oh sure, the granny will thank them for the visit and the presents with tears in her eyes, but really what she is crying over is her loneliness before the visit, and thinking about what lies ahead. It is my opinion that longing and loneliness lead to premature dementia. There is too much time to dwell upon your thoughts and nobody to break the chain of sad memories, and we all have those. It is human contact that keeps you abreast of things. (12/2005 ET) 
International Journal of Ageing and Later Life

Here, the writer identifies loneliness of older people mostly with a lack of human relationships and neglect by relatives. She also writes about a lack of meaning in life and being forgotten by society since nobody takes care of older people. Of the six portrayals identified above, only loneliness as a positive experience and inevitable part of old age are not present in this text. A detailed analysis of this extract is presented later in this article.

\section{Lack of Human Relationships}

Previous studies have often defined loneliness as a deficiency in social relationships and lack of contact with others (de Jong Gierveld 1987; Wenger \& Burholt 2004). At its simplest, being lonely is synonymous with a yearning for company and suffering as a result of being alone. However, our data show that in public talk loneliness is connected to a variety of psychological, social and cultural phenomena. The next extract, which is an excerpt from an editorial written by a journalist, presents a typical example of the traditional construction of loneliness.

... The saddest and unfortunately also the most frequent case of social silence is a lonely old man or woman who has absolutely nobody to talk to. Especially now that the popular TV news anchorman Arvi has retired. When you do not talk, your words, thoughts, and emotions start to wither away. Eventually you yourself will wither away too. (24.12.2004 HS)

The lack of human relationships is here presented as a typical tragedy for an older person; there is absolutely nobody to talk to. "A lonely oldie" is actually being constructed as a social category, which is here used as a tool for political argumentation and as a sign of collective or societal "disease". The climax of loneliness is the loss of contact with a TV personality. The lack of company is here constructed as the main reason for loneliness. Generally, however, while this reasoning is often present in the texts and in all text types, loneliness is rarely viewed purely as a lack of company. Friends and companions do not necessarily alleviate loneliness as the next excerpt attempts to show.

... When outdoors, $\mathrm{R}$ even talks to strangers. She does have friends but still - during the quiet moments, loneliness oppresses her.... "Last winter, I started feeling 
depressed and lonely. Especially in the evenings when I sat here and stared at the darkness. No one called or came to visit. I felt worthless." (1.6.2003 HS)

In this excerpt, written by a journalist, the old woman is positioned as an active and spontaneous actor, yet she is lonely. There is a substantial discrepancy between the subjective experience of loneliness and the apparent behaviour viewed by an outsider. The active efforts of the old woman actually underline the intensity of her inner loneliness, which is here described as a kind of depressive mood.

\section{Forgotten by Society}

Sometimes loneliness is associated with the low status of older people in society. Old people are represented as forgotten by society and the inhumanity of elderly care is emphasised. The next citation is an excerpt from a column written by the leader of an organisation working to alleviate loneliness.

\footnotetext{
... One word is enough for the lack of presence: Loneliness. Social exclusion and depression follow quickly. Older people - together with children - pay the most chilling price for the lack of presence in contemporary Finland. The aged are the group which has gotten the least attention in mental health work. ... Older people's biggest problems are loneliness, depression, and the increased suicide risk which follows. It might come as a surprise, but older people do commit suicide. In Finland, every other day, an older person decides to take his or her life. (4/2003 ET)
}

The writer emphasises the marginalisation of older people in society: they are invisible and forgotten by society. The writer has chosen a highly expressive style with drastic generalisations. He mentions many threats, such as alienation, depression and suicide. The same expressive style characterises all texts by this particular and very active writer. In two of his writings, he uses the word "battle" when referring to the efforts to alleviate loneliness (1/2005 ET; 16.11.2006 HS). The provocative style, together with the writer's position in society, may be effective if the intention is to agitate and arouse people or induce pity and guilt in readers. The writer represents an organisation that needs volunteers as well as financial support, and therefore provocation may be beneficial. On the other hand, a provocative style of writing is also welcomed by media. It can even be 
International Journal of Ageing and Later Life

called a standard that writers intensify, dramatise and simplify their messages in order to get more attention. However, dramatic expressions may increase anxiety in older people as well as in their relatives.

\section{Lack of Meaning in Life}

The absence of significant relationships is brought up in many texts in the same ways as in scientific texts (Pinquart \& Sörensen 2001; Routasalo et al. 2006; Victor et al. 2000). In the data the death of a spouse or the children living far away is assumed to cause longing and a feeling that there is "nobody to care for" (10/2006 ET). The days and weeks of an old person are characterised as waiting, getting bored and being dependent on other people. The lack of meaningful activities and significant relationships is often portrayed through metaphors. Older people are described as "the flies in the bottle" (29.3.2004 HS) or "prisoners in their homes" (8.5.2006 HS). The portrayals of declining resources and diminishing physical capacity are reflected in the metaphors. The next citation is an extract from an interview with a 76-year-old woman. The central issue here is the closing of the day hospital.

... GN, a 76-year-old woman who lives in Kallio, is in the day hospital Sofia for the third time. "I came here for the first time a couple of years ago." She is worried about losing the only way she can relax. "Because walking is difficult for me, I cannot go out. And because my friends are old too, I'm often alone. If it wasn't for this, I would be at home staring at the wall." (26.8.2003 HS)

The woman finds meaningful activity and social contacts at the day hospital. Especially in the HS, there are plenty of articles about activities organised by different service providers. The comments of older people about the clubs, meetings and discussion groups are positive without exception. These activities provide escape from everyday routine and also alleviate loneliness. Although older persons are interviewed in some texts, the activities are often described from the viewpoint of organisers or outsiders. It seems that from their perspective any relationship is good enough for an older person and that "professional friends" could suffice as the source of meaning in life (3.12.2003 HS). 


\section{Neglect by Relatives}

In the context of loneliness, the role of relatives appears contradictory. Both empathic and critical tones are present when dealing with this issue. The question of moral responsibility positions the relatives either as neglectful or exhausted by their many responsibilities and thus unable to care for their older family members. The relationship between children and aged parents is often a concern in the scientific literature, but the results for loneliness are also contradictory (Drageset 2004; Zhang \& Hayward 2001; Zhang \& Liu 2007). Neglect of older people by relatives is fairly seldom addressed in the texts. The few texts with this portrayal - especially the letters of the readers - are generally very affective with tones of guilt built in them. Old people are described as abandoned and forgotten, waiting for their relatives in hospital beds or having professional home help as their only social contact. Old people themselves are positioned as passive objects, capable only of waiting.

The first citation of this article is from the letter of a reader, who uses the pseudonym mother-in-law still going strong. On the first six lines in that excerpt the writer suggests that the loneliness of older people is a result of the neglect by relatives. She complains that even if the children have no time to come and visit the older mother or father, they have still time for long vacations. They do not spend enough time with older family members, and thus are not aware of their life situation. The relatives bring material gifts which are not even needed by the old parent, but they are not available when older parents need help. This text equates loneliness with a feeling evoked by a lack of a caring person. The writer appeals to the reader's sense of sympathy for a lonely old person's situation in order to catch the meaning of loneliness. It is not evident whether the writer is telling about the experiences of someone close to her, but the details of the text suggest this. The details create an impression of authenticity, as if they alluded to a personal knowledge of the matter. On the other hand, the pseudonym used by the writer constructs otherness. While she may not consciously realise it, she highlights the difference between herself (still going strong) and the forgotten old protagonist of her text. Such a writing style is common in the texts. It seems that people want to avoid being categorised as lonely older people. 
International Journal of Ageing and Later Life

\section{Loneliness as an Inevitable Part of Old Age}

Some articles consider loneliness as a natural part of old age. The writers emphasise that "ageing makes you feel lonely" (8/2003 ET), and loneliness is "an inevitable part of ageing" (8/2005 ET). The next excerpt comes from an interview with a photographer, who has conducted a photography project with older people. She discusses whether it is better to live at home or in an institution when you are old.

... "All older people are lonely, it is a part of being old. But still, wouldn't it be better if there was a community around you?", she contemplates. (23.11.2003 HS)

In this excerpt, loneliness and old age are strongly connected. However, there is a certain paradox in the writings conveying this connection: loneliness is understood as inescapable, yet actions are demanded to alleviate loneliness. The writers do not represent a particular group - they may be journalists as well as older people themselves or people from volunteer organisations. From the moral perspective the paradox of loneliness may be somewhat relieving: it is possible to do something to alleviate loneliness, yet it is unimaginable that loneliness as such could be removed from old age.

\section{The Possibility of Positive Loneliness}

In the scientific articles, especially in surveys, loneliness is widely seen as a solely negative state. In contrast, our data set includes a few texts where loneliness is constructed as a positive state. All of these texts are written from a subjective viewpoint. Here, the older person is positioned as an active person, "a third ager" who has chosen to be alone. Positive loneliness was rarely described after the active phase of the third age. The next text is an excerpt from an interview with a novelist.

... Good loneliness. MK has enjoyed being alone for about ten years. It gives her the freedom to write. - Loneliness is a great pleasure, although many do not believe it. $(15 / 2007$ ET)

The text suggests that solitude, silence and privacy are necessary requirements for creative work. Furthermore, positive loneliness is not 
merely a prerequisite for writing or painting, but it also has other beneficial meanings. Expressions such as "blessed loneliness" (24.4.2004 HS) and "enjoying aloneness" are examples of these (6/2003 ET). In the excerpt, MK argues that many people do not believe in positive loneliness. Positive loneliness seems to be based on freedom and voluntariness. In previous studies, loneliness as a subjective experience has been constructed in several ways. As shown by a Finnish study, the meanings of loneliness in old age given by old people themselves, include independence, peace and privacy, and a conscious decision to be alone (Palkeinen 2005a), but also lack of meaningful activity, a sense of insecurity, feelings of being an outsider and longing (Palkeinen 2005b). In the Finnish language, there is only one word for loneliness, which describes both negative and positive aspects of loneliness.

\section{How Should Loneliness Be Dealt With?}

The analysis showed that alleviation of loneliness was a crucial theme when loneliness and old age were covered in the media. The writers and interviewees often treated loneliness as a problem that should be avoided. The newspaper included in the study, HS, had a great many texts about alleviating loneliness. Among the writers, there is a considerable agreement that something should be done to alleviate loneliness among older people. The reasons for this vary, as do the perspectives. Negative consequences for individuals are frequently mentioned: suffering, feelings of worthlessness, insecurity and health problems, difficulty recovering from illnesses and increased risk of suicide. These consequences of loneliness have also been reported by previous studies (see Cacioppo et al. 2002; Heikkinen \& Kauppinen 2004). In the data, from the perspective of society, loneliness is said to be related with health expenses, inhumanity of care and marginalisation of older people. Loneliness is thus constructed as a problem for society as well as for individuals, and thus solutions are needed. The tone of the writings varies from neutral to very affective.

... The theme of the recent Mental Health Week was Alone amidst Everything. The theme affects many of us; loneliness is not something to play with. Everyone who has really suffered from loneliness knows how big a risk it is. Loneliness induces feelings 
International Journal of Ageing and Later Life

of worthlessness, insecurity and exclusion. Being alone can be positive, if it is voluntary. But when there is no alternative, loneliness hurts and paralyses you. (3.12.2006 HS)

In this excerpt from an editorial, negative consequences of loneliness are listed. According to research, some further ill-effects include psychological distress: anxiety, depression and boredom (see Killeen 1998). The negative consequences and the frequency of loneliness are presented as common knowledge not to be questioned. Only very rarely did the writers refer to their own experiences. The position of an outsider seems to offer an opportunity to use strong expressions. However, there are also emotionally neutral texts, written from the position of an outsider, such as in the next excerpt from news.

... According to researchers, loneliness raises health expenses. According to KP, a medical doctor specialised in elderly care, those who are lonely are more likely than others to get illnesses such as depression and dementia. (1.6.2003 HS)

The writer refers to scientific studies and to a medical authority in order to make her argument more plausible. Loneliness is here addressed from the scientific viewpoint. The matter-of-fact style makes the account appear as if it came from a research report. The data contain many texts dealing with the connection between loneliness, health problems and abuse of alcohol, but health expenses are rarely mentioned. These are mentioned exclusively by researchers and health and social care professionals. It seems that bringing up the economic viewpoint is here used as an effective strategy to call the policymakers' attention to the issue of loneliness. However, the economic discourse may in fact divert readers from seeing loneliness as an individual experience.

Many writers suggest remedies for alleviating loneliness. The spectrum of the suggestions ranges from broad and collective responsibility to sporadic and perfunctory solutions. In the next excerpt, coming from a column, the suggestion involves all people collectively.

... It is not sad when people have lain dead in their apartments for who knows how long. What is sad is that an old person lives in total oblivion. It is the culmination of loneliness. Trying to find someone to blame is useless. The authorities cannot take all responsibility for taking care of them - not to mention remembering and caring. The 
working population, mummified by their everyday busyness, cannot be collectively obliged to work in voluntary senior care groups either. Still, something should be done. Saying hello to or having a few words with the older person next door could be a good start. (12.3.2006 HS)

In this excerpt, the solution lies in enhanced interaction between people in general. Nobody in particular is to blame or held responsible; rather, it is the general atmosphere or collective attitude that needs to be changed. Comparably to "saying hello to the old person next door", some writers suggest that people should try to "restore a culture, where people take care of their neighbours who live alone" (3.9.2003 HS) or claim that "every one of us has an opportunity to care for other people" (3.12.2003 HS). Some of the suggestions are fairly naïve or perfunctory, such as the suggestion that schoolchildren should regularly phone older people living in the neighbourhood (16/2007 ET). Pragmatic measures are also suggested, such as discounted travel on local transport, radio programmes aimed at older people or virtual services. These suggestions often seem to be written from the layman's point of view. In the next excerpt, the solution is a pet.

\footnotetext{
... A pet will relieve loneliness. Raili recommends everybody who complains of loneliness to get a pet. Maybe not a sheep, but a cat or a dog. Raili has both, more than one each. $(15 / 2005$ ET)
}

The person interviewed in this article has perceived the company of pets to relieve her loneliness, and she recommends these as a general strategy to anyone suffering from being alone. Here the responsibility is delegated to older persons themselves. Analogously, some writers suggest that older people find out places where they can meet other people (8/2007 ET) or take on a new hobby or a pen-friend or a friend from the internet (11.10.2004 HS). The idea behind these solutions seems to suggest that any kind of activity or company decreases loneliness.

In the majority of articles, the responsibility for alleviating loneliness is delegated to society and relatives. Paradoxically, however, the suggestions are rather abstract. Social interaction and activity are generally considered important for older people, and interested parties are expected to take action against loneliness, but otherwise, the demands remain rather 
International Journal of Ageing and Later Life

abstract. The next text is an exception: the writer, a medical practitioner, makes a concrete suggestion.

\begin{abstract}
... In taking care of lonely seniors, funding relevant research or opening cafés is not enough. The voters as well as decision-makers hopefully have enough common sense and compassion to recognise what is really needed, apart from research and statistics. What is needed is action, not talk. The money should be spent on hiring helping hands, perceptive eyes and listening ears. (8.5.2006 HS)
\end{abstract}

In this excerpt from a column, a strong argument is made. The writer calls for prioritisation in terms of money and more staff in elderly care. Current attempts to alleviate loneliness with research or meeting places are portrayed as useless and even naïve. Common sense should be applied instead of research. The provocative style is probably directed at decisionmakers, and the frustration with the benefits of research seems all the more persuasive coming from an academic. The writer is irritated and frustrated in the face of powerlessness to alleviate loneliness, but many even more distressing accounts are found in the data. One of these is a letter from a reader, relating to her own parents. The writer herself is not able to meet her parents' needs, and she is desperate about who should help. For her, as well as for many other writers, the ideal solution is communal living, where "older people keep each other company and no staff is needed" (26.3.2007 HS). None of the writers refers to the problems inherent in this type of arrangement, namely generational segregation. Besides, previous studies have shown that older people living in institutions or residential homes are more likely to suffer from loneliness than community-dwelling elders (Jylhä 2004; Savikko et al. 2005). The living arrangement suggested by the writers may be something more than simply living together in the same building.

The magazine and the newspaper in this study have very different profiles, but the writings about loneliness are fairly similar (cf. differences in previous studies; see Lumme-Sandt 2010; Rozanova 2006; Vakimo 2001; Williams et al. 2010). HS seemed to emphasise societal aspects more whereas ET emphasised emotional aspects. However with this data of different medias we were able to form a quite comprehensive view of the cultural understanding of loneliness in Finland. 
A study on loneliness of older people

\section{Discussion}

In the scientific literature, loneliness has been defined in several ways. It is often defined as a deficiency in a person's social relationships as well as a subjective feeling. Loneliness has also been described as an unpleasant and distressing condition (Peplau \& Perlman 1982). Even if those attributes are present in the data, loneliness is rarely seen solely from the perspective mentioned above. In our data, loneliness was charged with many other unpleasant and even dangerous things. The meaning of loneliness may differ from one individual to another because of the subjective and contextspecific nature of the concept (Killeen 1998). It appears that in our culture, loneliness as a negative concept is easily associated with various unpleasant and negative attributes. It may also have negative consequences, such as physical symptoms, depression and suicidal behaviour, which are talked about from both the scientific and the layman's points of view. In this study loneliness is represented as lack of human relationships, being forgotten by society, lack of meaning in life, neglect of older people by relatives, an inevitable part of old age and also positive loneliness, but also significance of alleviation of loneliness as well.

Even if the solely negative portrayal of older people seems to be changing in media, and people in the third age are portrayed in affirmative ways (Williams et al. 2007), older people in the fourth age are mostly constructed in a negative way (Bonnesen \& Burgess 2004; Rozanova 2006). The data presented here clearly show that there are two different conceptions/representations of old age at the moment. The first is the active and productive third age, which is characterised by pleasure, and the second is the weak and passive fourth age, constructed as suffering caused by disease and dependency on others (see Weiss \& Brass 2002). In this study, the loneliness of the third age is represented mostly as a temporary or even positive feeling, whereas loneliness in the fourth age seems to be very different: it has negative consequences and is difficult to avoid. It seems that negative stereotypes as well as the demands to alleviate loneliness are located in the fourth age. The fourth age - the "actual" old age - appears to include the attributes of loneliness and illnesses, and it would be absolutely impossible for the weak and sick old people to be socially active. 
International Journal of Ageing and Later Life

The media is one vehicle for shaping attitudes towards age and ageing, and it has often been blamed for perpetuating ageism and cultural stereotypes about seniors, particularly older women (Carrigan \& Szmigin 2002; Cohen 2002). Even then the studies of the media rarely look at ageism. Vakimo (2001) and Mulley (2007) summarised that newspapers tend to write about older people in a problem-oriented way. Old age is described as an illness, dependency and a threat to the economy and healthcare system (Mulley 2007; Vakimo 2001). Inaccurate and biased images of older people and also under-representations in media are seen as ageism (Hilt \& Lipschultz 2005; Vernon et al. 1990). In our data, focusing on loneliness, older people are almost solely portrayed in negative ways. Constructing older people as victims of loneliness because of their age is a form of ageism. In our data, loneliness is partly represented as a consequence of ageing and thus as an inseparable part of old age. However, the images of older people are not solely negative or ageist in media. There are magazines, including the ET magazine, which clearly address the positive aspects of ageing and can even be described as anti-ageist (Lumme-Sandt 2010; Williams et al. 2007). In this study, the selection criteria excluded the texts which dealt with ageing in some other context than loneliness. Therefore, our data do not allow conclusions concerning the presence or absence of ageism in ET and HS.

In most of the texts, the writers view old age loneliness from an outsider's position (see Vakimo 2001). The outsider's position seems to legitimise a more provocative style and moral irritation than a position where the writer discusses his/her own loneliness. However, loneliness as a personal experience is rarely present in the texts. In those texts, loneliness is presented as a complicated phenomenon, and it is often connected with concepts of the third age. To write or talk about one's own loneliness seems to require a certain amount of empowerment. On the other hand, previous literature has shown that older people may view loneliness as a stigma, and are therefore reluctant to discuss it. It may be embarrassing to admit that you are lonely (Killeen 1998; McInnis \& White 2001). Positioning lonely older people as others (see Anderson 2007; Kulmala 2006), enables the writers to avoid the negative stigma of loneliness. "A lonely old person" is a category to which people do not want to belong. The shamefulness of loneliness might connect to the feeling that loneliness 
is a person's own fault and there is something wrong with a lonely person because she/he cannot form relationships. In the data of this study, lonely older people are constructed as pitiable and sometimes texts evoke empathy of the readers.

The writer's position necessarily affects the perspective on loneliness as well as the style of writing. In these data, the strongest voices often belong to those whose work is somehow connected to the area of alleviating loneliness. This could be an attempt to arouse discussion, but also a way of marketing "loneliness industry". Talking about "a battle" against loneliness hints at the role and importance of various organisations. The organisations may legitimise their existence in that way. A large part of the actors involved in alleviating loneliness among older people are non-profit organisations whose primary purpose is not selling, but it seems that loneliness sells. Rokach (2004) argues that a loneliness industry has been developed to meet the desire of those who do not know what to do about their loneliness. The loneliness business includes semi-forced joint activities, mate-finding agencies and self-help books, and it is a growing business (Rokach 2004).

In the scientific literature, several interventions and programmes for alleviating loneliness have been introduced, most of them have not been effective (Cattan et al. 2005a; Findley 2003). Our data include many perfunctory and even naive solutions to the problem of loneliness. Some involve the whole society while others are just isolated actions. Previous studies have not addressed the fact that the low status of older people in society or the alleged inhumanity in elderly care may cause feelings of loneliness. Improving the social status or elderly care practices would then be one solution to alleviate loneliness. However, in our data the suggestions are often presented as universal solutions. The scientific loneliness literature, however, comes up with a different view: solitary interventions do not apply universally to alleviation of loneliness (Findley 2003). The anxiety induced by loneliness probably makes the writers desperate to try to find solutions and offload the responsibility of alleviating loneliness on to someone else.

In the articles dealing with the alleviation of loneliness, older people are typically cast as objects in the mass media. Other people should organise activities, collect money, help and take care of older people. This kind of 
International Journal of Ageing and Later Life

writing constructs older people as passive persons who do not have the opportunity to influence their lives and make decisions. It seems as if older people themselves are not even expected to take action. Previous research has reached a similar conclusion. Cattan and colleagues (2005b), for example, found that activities are usually built on professional assumptions, and older people are rarely involved in planning and implementing programmes; other people seem to know better what is best for older people.

According to our data, loneliness is often represented as a political issue. There is a dispute over who is responsible for alleviating loneliness among older people. The voluntary organisations appear to be the main actors but the responsibility is shifted to the decision-makers and collectively to society. The texts are often written from the viewpoint of voluntary work. Sometimes the writers refer to the role of older people themselves in alleviating loneliness. In research, older people have reported that reading, gardening and watching television alleviate loneliness (Palkeinen 2005a; Pettigrew \& Roberts 2008), but in the texts of this study, there are only few mentions of these activities. The emphasis is on social activities where other people play the active role. Only in a few texts are older persons themselves considered as agents who could phone or visit their children and grandchildren or take the first step to contact the younger generation. Contacts between generations are seen almost solely as the responsibility of the younger generation.

These findings were based on print media, so there is a need for further research about portrayals of loneliness in the different media types internationally, for example, in TV-programmes, films, internet as well as literature. Previous studies have shown that alleviation of loneliness is difficult, therefore it is important to know more about the construction of loneliness and identify all dimensions which are attached to it in our society. When loneliness in better understood and conceptualised, it would be also easier to build effective programmes aimed to relieving loneliness.

Although the importance of relieving loneliness is often discussed on a general level, loneliness is simultaneously presented as a natural part of ageing. The prevalence of loneliness and inseparability of loneliness and old age are constructed as mutually shared knowledge in our society. It seems that in Finnish print media, the typical lonely person is old, and the 
typical older person is lonely. However, lonely older people are often constructed as outsiders in human relationships, and also outsiders in society.

\section{Corresponding Author}

Hanna Uotila, Tampere School of Public Health, FI-33014 University of Tampere, Finland. Email: hanna.uotila@uta.fi

\section{References}

Anderson, K. T. (2007). Constructing "otherness": Ideologies and differentiating speech style. International Journal of Applied Linguistics 17(2): 178-197.

Bazzini, D. G., McIntosh, W. D., Smith, S. M., Cook, S. \& Harris, C. (1997). The ageing woman in popular film: Underrepresented, unattractive, unfriendly, and unintelligent. Sex Roles 36(7/8): 531-543.

Bonnesen, J. L. \& Burgess, E. O. (2004). Senior moments: The acceptability of an ageist phrase. Journal of Aging Studies 18(2): 123-142.

Cacioppo, J. T., Hawkley, L. C., Crawford, E., Ernst, J. M., Burleson, M. H., Kowalewski, R. B., Malarkey, W. B., Van Cauter, E. \& Berntson, G. G. (2002). Loneliness and health: Potential mechanisms. Psychosomatic Medicine 64(3): 407-417.

Carrigan, M. \& Szmigin, I. (2002). Advertising and older consumers: Image and ageism. Business Ethics: A European Review 9(1): 42-50.

Cattan, M., White, M., Bond, J. \& Learmonth, A. (2005a). Preventing social isolation and loneliness among older people: A systematic review of health promotion interventions. Ageing \& Society 25(1): 41-67.

Cattan, M., White, M., Learmonth, T. A. \& Bond, J. (2005b). Are services and activities for socially isolated and lonely older people accessible, equitable, and inclusive? Research, Policy and Planning 23(3): 149-164.

Cohen, H. L. (2002). Developing media literacy skills to challenge television's portrayal of older women. Educational Gerontology 28(7): 599-620.

Drageset, J. (2004). The importance of activities of daily living and social contact for loneliness: A survey among residents in nursing home. Scandinavian Journal of Caring Science 18(1): 65-71. 
International Journal of Ageing and Later Life

Edley, N. (2001). Analysing masculinity: Interpretative repertoires, ideological dilemmas and subject positions. In M. Wetherell, S. Taylor \& S. Yates (eds.), Discourse as Data. A Guide for Analysis (pp. 189-228). London: Sage.

Ellis, S. R. \& Morrison, T. G. (2005). Stereotypes of ageing: Messages promoted by age-specific paper birthday cards available in Canada. International Journal of Aging and Human Development 61(1): 57-73.

Findley, R. A. (2003). Interventions to reduce social isolation amongst older people: Where is the evidence? Ageing $\mathcal{E}$ Society 23(5): 647-658.

Finnish Audit Bureau of Circulations. (2009). KMT lukija syksy 2007/kevät 2008. [KTM the Reader Autumn 2007/Spring 2008]. Helsinki: Finnish Audit Bureau of Circulations. Available on http://www.levikintarkastus.fi/ mediatutkimus/KMT_Lukija_S07-K08_paakohderyhmat.pdf (Accessed: February 23, 2009).

Heikkinen, R-L. \& Kauppinen, M. (2004). Depressive symptoms in late life: A 10-year follow-up. Archives of Gerontology and Geriatrics 38(3): 239-250.

Hilt, M. L. \& Lipschultz, J. H. (2005). Mass Media, An Aging Population, and the Baby Boomers. Mahwah, NJ: Lawrence Erlbaum Associates.

Horton, S., Barker, J. \& Deakin, J. M. (2007). Stereotypes of aging: Their effects on the health of seniors in North American Society. Educational Gerontology 33(12): 1021-1035.

de Jong Gierveld, J. (1987). Developing and testing a model of loneliness. Journal of Personality and Social Psychology 53(1): 119-128.

Jylhä, M. (2004). Old age and loneliness: Cross-sectional and longitudinal analyses in the Tampere longitudinal study on aging. Canadian Journal on Aging 23(2): 157-168.

Jylhä, M. \& Saarenheimo, M. (2010). Loneliness and aging: Comparative perspectives. In C. R. Phillipson \& D. Dannefer (eds.), The SAGE Handbook of Social Gerontology (pp. 317-328). Thousand Oaks, CA: Sage.

Killeen, C. (1998). Loneliness: An epidemic in modern society. Journal of Advanced Nursing 28(4): 762-770.

Kulmala, A. (2006). Kerrottuja kokemuksia leimatusta identiteetistä ja toiseudesta [Narrated Experiences of Stigmatised Identity and Otherness]. Tampere: Acta Universitatis Tamperensis. 
Laslett, P. (1989). A Fresh Map of Life. The Emergence of the Third Age. London: Weidenfeld and Nicolson.

Lumme-Sandt, K. (2010). Images of ageing in a 50+ magazine. Journal of Aging Studies. DOI: 10.1016/j.jaging.2010.08.013.

McInnis, G. J. \& White, J. H. (2001). A phenomenological exploration of loneliness in the older adult. Archives of Psychiatric Nursing 15(3): $128-139$.

Medianetti. (2009). HS Product Family. Helsinki: Helsingin Sanomat. Available on http://medianetti.helsinginsanomat.fi/english/HS+ Product + family/1101979183413 (Accessed: February 23, 2009).

Miller, D. W., Leyell, T. S. \& Mazachek, J. (2004). Stereotypes of the elderly in U.S. television commercial from the 1950s to the 1990s. International Journal of Aging and Human Development 58(4): 315-340.

Miller, L. (2008). Foucauldian constructionism. In J. A. Holstein \& J. F. Gubrium (eds.), Handbook of Constructionist Research (pp. 413-428). New York: The Guilford Press.

Miller, P. N., Miller, D. W., McKibbin, E. M. \& Pettys, G. L. (1999). Stereotypes of the elderly in magazine advertisements 1956-1996. International Journal of Aging and Human Development 49(4): 319-337.

Mulley, G. (2007). Myths of ageing. Clinical Medicine 7(1): 68-72.

Palkeinen, H. (2005a). "Tässä on kaikki parasta, nyt kun mä elän yksin." Yksin olemisen hyvät puolet iäkkäiden naimattomien naisten puheessa [Single, elderly women's attitudes toward solitude]. Naistutkimus 18(1): 30-41.

Palkeinen, H. (2005b). Yksinäisyys iäkkäiden ihmisten kirjoituksissa [Loneliness in the texts of elderly people]. Gerontologia 19(3): 111-120.

Peplau, A. L. \& Perlman, D. (1982). Perspectives on loneliness. In A. L. Peplau \& D. Perlman (eds.), Loneliness: A Sourcebook of Current Theory, Research and Therapy (pp. 1-18). New York: John Willey.

Pettigrew, S. \& Roberts, M. (2008). Addressing loneliness in later life. Aging \& Mental Health 12(3): 302-309.

Pierce, L. L., Wilkinson, L. K. \& Anderson, J. (2003). Analysis of the concept of aloneness. As applied to older women being treated for depression. Journal of Gerontological Nursing 29(7): 20-25. 
International Journal of Ageing and Later Life

Pinquart, M. \& Sorensen, S. (2001). Influences on loneliness in older adults: A meta-analysis. Basic \& Applied Social Psychology 23(4): 245-266.

Rokach, A. (2004). Loneliness then and now: Reflections on social and emotional alienation in everyday life. Current Psychology 23(1): 24-40.

Routasalo, P. E., Savikko, N., Tilvis, R. S., Strandberg, T. E. \& Pitkälä, K. H. (2006). Social contacts and their relationship to loneliness among aged people - a population-based study. Gerontology 52(3): 181-187.

Roy, A. \& Harwood, J. (1997). Underrepresented, positively portrayed: Older adults in television commercials. Journal of Applied Communication Research 25(1): 39-56.

Rozanova, J. (2006). Newspaper portrayals of health and illness among Canadian seniors: Who ages healthy and at what cost? International Journal of Ageing and Later Life 1(2): 111-139.

Sanoma Magazines Finland. (2009). ET-lehti. [The ET Magazine]. Helsinki: Sanoma Magazines Finland. Available on http://asiakaspalvelu. sanomamagazines.fi/tutustu/default.asp?lehti=ET (Accessed: February 23, 2009).

Savikko, N., Routasalo, P., Tilvis, R. S., Strandberg, T. E. \& Pitkälä, K. H. (2005). Predictors and subjective causes of loneliness in an aged population. Archives of Gerontology and Geriatric 41(3): 223-233.

Steed, L., Boldy, D., Grenade, L. \& Iredell, H. (2007). The demographics of loneliness among older people in Perth, Western Australia. Australasian Journal on Ageing 26(2): 81-86.

Taylor, S. (2001). Locating and conducting discourse analytic research. In M. Wetherell, S. Taylor \& S. Yates (eds.), Discourse as Data. A Guide for Analysis (pp. 5-48). London: Sage.

Toppila, M. (2009). Suomen suurin aikakauslehti [The Largest Magazine in Finland]. Helsinki: Sanoma Magazines Finland. Available on http:// www.sanomamagazines.fi/mediaopas/kohderyhmat-ja-lehdet/lehdet/ et.html (Accessed: February 23, 2009).

Vakimo, S. (2001). Paljon kokeva, vähän näkyvä. Tutkimus vanhaa naista koskevista kulttuurisista käsityksistä ja vanhan naisen elämänkäytännöistä. [Out of Sight But Full of Life. A Study of Cultural Conceptions of Old 
Women and Their Life Practices]. Helsinki: Suomalaisen Kirjallisuuden Seura.

Vernon, J. A., Williams, Jr. J. A., Phillips, T. \& Wilson, J. (1990). Media stereotyping: A comparison of the way elderly women and men are portrayed on prime-time television. Journal of Women \& Aging 2(4): $55-68$.

Victor, C., Scambler, S., Bond, J. \& Bowling, A. (2000). Being alone in later life: Loneliness, social isolation and living alone. Reviews in Clinical Gerontology 10(4): 407-417.

Victor, C. R., Scambler, S. J., Bowling, A. \& Bond, J. (2005). The prevalence of, and risk factors for, loneliness in later life: A survey of older people in Great Britain. Ageing \& Society 25(3): 357-375.

Vincent, J. (2003). Old Age. London: Routledge.

Weiss, R. S. (1973). Loneliness. The Experience of Emotional and Social Isolation. Cambridge: The MIT Press.

Weiss, R. S. \& Brass, S. A. (2002). Introduction. In R. S. Weiss \& A. S. Brass (eds.), Challenges of the Third Age: Meaning and Purpose on Later Life (pp. 3-12). New York: Oxford University Press.

Wenger, G. C. \& Burholt, V. (2004). Changes in level of social isolation and loneliness among older people in a rural area: A twenty-year longitudinal study. Canadian Journal on Aging 23(2): 115-127.

Wetherell, M. \& Edley, N. (1999). Negotiating hegemonic masculinity: Imaginary positions and psycho-discursive practices. Feminism Psychology 9(3): 335-356.

Wetherell, M., Taylor, S. \& Yates, S. (eds.). (2001). Discourse as Data. A Guide for Analysis. London: Sage.

Williams, A., Wadleigh, P. M. \& Ylänne, V. (2010). Images of older people in UK magazine advertising: Towards a typology. The International Journal of Aging and Human Development 71(2): 83-114.

Williams, A., Ylänne, V. \& Wadleigh, P. M. (2007). Selling the "Elixir of Life": Images of the elderly in an Olivio advertising campaign. Journal of Ageing Studies 21(1): 1-21.

Wood, L. A. \& Kroger, R. O. (2000). Doing Discourse Analysis. Methods for Studying Action in Talk and Text. Thousand Oaks, CA: Sage. 
International Journal of Ageing and Later Life

Zhang, W. \& Liu, G. (2007). Childlessness, psychological well-being, and life satisfaction among the elderly in China. Journal of Gross Cultural Gerontology 22(2): 185-203.

Zhang, Y. B., Harwood, J., Williams, A., Ylänne-McEven, V., Wadleigh, P. M. \& Thimm, C. (2006). The portrayal of older adults in advertising. A cross-national review. Journal of Language and Social Psychology 25(3): 264-282.

Zhang, Z. \& Hayward, M. D. (2001). Childless and the psychological wellbeing of older persons. Journal of Gerontology: Social Science 56B(5): S311-S320. 